\title{
EXPLORACIONES TRANS(T)EX(T)UALES Y ACERCAMIENTOS A LO POSHUMANO EN LAS OBRAS NEOBARROCAS DE LA ESCRITORA (Y ARTISTA VISUAL) CHILENA EUGENIA PRADO
}

\author{
POR \\ KRYSTOF KULAWIK \\ Central Michigan University
}

Se nos presenta como ofrenda, una aparición, animal extraño, un animal que no puede ser clasificado desde su continente.

Eugenia Prado. ${ }^{\mathrm{b}}$ Hembros (11)

La noción de subjetividad, especialmente en relación con la identidad sexual, resulta subversivamente desestabilizada en las obras de la escritora contemporánea chilena, Eugenia Prado. Este asedio a la identidad estable se produce con la presencia de múltiples personajes que parecen autómatas o cyborgs andróginos, caracterizados por una metamorfoseante des-identidad, a veces llamada "poshumana" por la crítica reciente (Haraway, Hayles, Brown, Poblete). Por medio de estos personajes, se incursiona en los terrenos limítrofes de la psiquis humana en novelas experimentales como El cofre (1987), Lóbulo (1998) y en la novela-instalación Hembros (2004). Estas representaciones apuntan hacia un fenómeno cultural que se podría describir como una "crisis de identidad", entendida como una dispersión de referentes estables de lo que constituye la subjetividad. Se desintegran las identidades coherentes al cruzar los límites de género, etnia y de lo (in-)humano, a tal punto que los textos mismos que las contienen no se pueden clasificar en un género literario tradicional. La deconstrucción de categorías de género sexual y, al mismo tiempo textual, se realiza por medio de la misma lengua que conforma los textos narrativos, confiriéndoles un sentido político radical. Los rasgos que prevalecen en varios de los personajes y que forman un hilo conector de todas estas obras son la mutabilidad, movilidad y transitividad de estos sujetos en cuanto a su apariencia, comportamiento y sexualidad. Del mismo modo, el discurso se desestabiliza y se metamorfosea para incluir fragmentos poéticos y dramáticos dentro de un tejido narrativo altamente híbrido.

La presencia de la identidad poshumana, de lo que se ha venido a llamar cyborg, ya ha sido puntualizada en los análisis de la novela Lóbulo realizados por J. Andrew Brown y Nicolás Poblete, quienes se basan tanto en los conceptos de teóricos más 
tempranos como Gilles Deleuze y Félix Guattari como en estudios posteriores de Donna Haraway y N. Katherine Hayles. El estudio de Brown parte de la definición de Hayles sobre el cyborg: "un ser híbrido de carne y aparato tecnológico que, por esa hibridez, desafía las clasificaciones de la sociedad tradicional [... y] representa la posibilidad de completar una identidad mutilada e incompleta [...]" (802). Produce couplings (acoplamientos o combinaciones) que en su deseo sexual generan placer a la vez que violan límites y fronteras de la identidad sexual e irrumpen las estructuras no sólo de la familia tradicional sino también de cualquier categorización convencional en cuanto a género (802). Refiriéndose a Deleuze y Guattari, Poblete observa el carácter binario de las máquinas y aparatos, pues desean acoplarse con otro: "schizophrenia is the universe of productive and reproductive desiring machines [...] Desiring-machines are binary machines, obeying a binary law or set of rules governing associations: one machine is always coupled with another" (Deleuze y Guattari). De ahí, es posible explicar la escisión esquizoide de los protagonistas en algunas de las novelas de Prado, la que suele ocurrir en el ámbito de la ciudad alienante y en expansión, "un universo automático y posthumano" en el cual "[l]os espacios comienzan a ser avasallados por los encuentros externos que empiezan a degenerar las identidades [...]” (Poblete 3)

\section{HEMBROS}

En la producción artística de Eugenia Prado, la escisión de la identidad de los protagonistas alienados en un mundo hipertecnológico es ejemplificada en Hembros, una obra tan híbrida, transgenérica y multifacética como la idea misma del cyborg: rehúsa cualquier categorización de género (sexual y literario) por lo que constituye un proyecto fluido, texto-en-gestación, novela-instalación, escenificada con video y música. La obra textual original Hembros, comenzada en 1998, fue reelaborada con acompañamiento musical y escenificada en formato de novela-instalación con el título Hembros: asedios a lo post humano (2003-2004) que, según Prado, "propone la lectura de una novela desde otros soportes, es decir, sacándola del formato tradicional del libro" (Correspondencia 2). Se estrenó y se realizaron catorce funciones en el Galpón Víctor Jara de Santiago en 2004 como una "instalación escénica plástica", una "obra de artes integradas [... instalación multimedia, música original, teatro, danza, videoarte y plástica, en acople con tecnologías de punta, micrófonos, luces, amplificación" (Correspondencia 2-3), dirigida por el Colectivo de Artes Integradas (CAIN). John Streeter compuso la música para esta representación; la banda sonora contiene declamaciones de la novela-en-proceso escrita por Prado.

La novela-instalación explora la emergencia de sujetos dispersos y móviles perdidos en un mundo tecnológicamente desarrollado, para revelar, según la autora, "las interacciones entre los oficios y con las máquinas tecnológicas actuales" (Prado, correspondencia 2). Su objetivo es captar "los símbolos y signos de las fuerzas que en un ambiente tecnologizado, codificado, actúan como modelos imprimiéndose en las mentes y cuerpos hoy" (Correspondencia 2). El concepto multimediático de "la integración de los oficios la literatura, el teatro, la música, el movimiento, el diseño, la plástica, las máquinas audiovisuales y técnicas digitales" (Correspondencia 2) cruza todas las fronteras del género artístico. En este contexto, se presentan sujetos andróginos que desencadenan una rebelión contra el Padre -como figura abstracta de autoridad-y contra toda la institución tecnocrática que él representa. El motivo guiador es la constante búsqueda de un "otro". El/la protagonista, representado con el neologismo "hembro"-un ser andrógino que merodea entre los límites de lo femenino (hembra) y lo masculino (hombre)-, interpreta una letanía esquizofrénica de un despertar en un mundo hostil y de rebelarse contra el sistema patriarcal que categoriza, organiza y oprime al sujeto por medio de la tecnología. Este personaje está rodeado por imágenes y signos que literalmente lo/la bombardean de todos los lados mezclándose con los actos corporales escenificados por la actriz con sus movimientos, su pintura corporal, canciones y bailes. Dos pantallas, una a cada costado y una tercera que se dirige desde arriba contra el suelo, proyectan imágenes que actúan contra los movimientos y la representación del espectáculo, interviniendo las palabras de la creatura (hembro) en simultaneidad y desde diferentes ángulos. Múltiples voces hablan al mismo tiempo: “¿Quién, cuándo soy? ¿Cómo, cuando el amor no existe? Odiar al padre, odiarlos a todos ellos. Odiarlos a fuerza de la autoridad con odios que clamen sus mentiras [...]. Odiar a todos los padres y sus instituciones" (Prado, ${ }^{a} H e m b r o s$, Canto 1 "El amor no existe"). Entre las distintas voces que hablan en secuencia o simultáneamente, se distingue la del/la protagonista, el/la hembro andrógino/a. Prevalece una dimensión onírica en la cual los sueños no se distinguen de la realidad palpable, y esta última se funde con la textual, un mundo lingüístico formado de conceptos y palabras: " [...] con la sensación de atravesar sueños aterradores. Sueños que se relacionan con un estado que me hace desaparecer atrás de las palabras" ("Hembros, Canto 3 "Mercenario"). El personaje tiene conciencia de su otredad -una "alteridad" sexualmente ambigua- que lo/la distingue de su creador y de los demás - del tumulto-. Esta conciencia incita su rebelión y el deseo de liberación de las categorizaciones impuestas por el sistema de signos, convenciones formuladas por la maquinaria social y tecnológica: "Tengo esta apariencia extraña, mezcla ajena e insoportable que me excluye. Un ejemplo ambiguo en la necesidad de huir, salir de la tela, del propio tejido, librarse de no sé cuál de todas las trampas [...] ¿Dónde me atrapó la misma idéntica historia? Aprendí a someter esta forma mía femenina y ambigua" (Canto 4 "Artaud"). El personaje, con plena conciencia de su cuerpo ambisexual, lucha por autoconstituirse, reformularse, asumiendo una voz propia como gesto de poder. Toma la escritura como medio de expresión de su corporalidad y sexualidad problematizadas, pero termina siendo una máquina productora de textos, una impresora de signos, sin 
poder superar su convencionalidad: "Me someto, vuelvo a la trampa por no saber cómo avanzar este cuerpo repleto de signos, cuerpo que se agita y en su deseo atrapa. Cuerpo mío que en la curvatura daña porque tiene gestos de poder adentro, y porque sabe cómo degradar" (Canto 4 "Artaud").

La autoconciencia del/la cyborg adquiere una dimensión crítica ante la sumisión al control del sistema patriarcal imperante, acompañada por un inherente deseo de libertad, visible en los siguientes fragmentos: "Somos especies de autómatas, un género enfermo creado para situar el horror" (Canto 2 "Mercenario"). "Un imperio de cerebros mecánicos precipita nuestras imágenes" (Canto 8 "Madre barro").

El proceso de rebelión y autodefinición es representado por medio de palabras -el narrador-creador-Demiurgo- usa el mismo sistema lingüístico que en última medida deconstruirá al sujeto (y a sí mismo) dentro de un sistema de comunicación coherente y convencional. En una especie de diálogo que se desencadena entre el creador (escritor(a) narrador(a)) y el/la protagonista, las palabras se dispersan en intentos de definiciones al mismo tiempo que las ideas flotan libremente en nuevos territorios conceptuales, haciendo nuevas conexiones. Una de ellas es precisamente el indefinible "hembro", fonéticamente cercano y semánticamente relacionado con la palabra "embrión", para sugerir un comienzo o una nueva (des-) categorización. En la performance operática aparece la voz del/la creador(a) / escritor(a) para explicar: "HEMBRO: nombre que he dado en llamar a especies de ambos sexos, hombre femenino, hembra masculino, como nombre genérico que defina su condición, momentos antes de situarse en conceptos más elaborados y que me permitan incorporar ambos términos en una posible clasificación" (Canto 9 "Azumbro", mayúscula en original). La voz sigue aclarando: "Dos fuerzas opuestas en un mismo signo o una nueva instancia que nos traspase y nos permita el cambio de ángulos". Se descuellan la fluidez y movilidad de este nuevo concepto -de un sujeto transitivo-, según el comentario del/la creador(a) - narrador(a): “[...] todos los días la imagen, incluso tu propia imagen, puede ser modificada" (Canto 9 "Azumbro").

En una entrevista realizada por el autor de este artículo, Eugenia Prado describió "hembro" como un ser que transita de un espacio líquido a uno oxigenado, se levanta y empieza a caminar, hace preguntas existenciales en un discurso cruzado con el/la creador(a). Con el tiempo, las dos voces se mezclan y la criatura se funde con el/la creador(a) "en un cruce que se desarrolla como un montaje cruzado por las ideologías" (Entrevista 16). Sugiere que la libertad es relativa y no totalmente alcanzable cuando el sujeto se funde con el objeto de su creación, siempre guardando una relación de dependencia entre el uno y el otro -creador y creatura-. La voz del creador (el sistema) reacciona a la rebelión de su objeto-creatura-nuevo sujeto. Admite que este nuevo ser es una performance extraviada dentro de un mundo de estructuras, de una matriz que controla todo. Sugiere que no existe una realidad fuera de la forma impuesta, una convención de cuerpos humanizados, perfectos y oferta del mercado, al mismo tiempo que flexibles y transformables. Esta convención es la misma perdición del sistema creador, es la conciencia de la creatura -el hembro asume una voz rebelde y amorfa del andrógino. Observemos cómo se expresan estas ideas de la relación entre las dos instancias: "Aprendidos los disfraces, desde los espacios, extraños. Extraviados van asimilándose a las estructuras. Es el mundo entero el que destruye tus caderas redondeadas. Esa sexualidad tuya es ahora nuestra mejor oferta. ¿Desde cuáles síntomas nos permitirías identificar una realidad para tu forma? Cuerpos flexibles, humanizados, sutilizados y perfectos. Personajes transformados y diabólicos, ofertando la radicalidad de sus propuestas" (Canto 15 "Dulces vibraciones"). La pérdida de la estabilidad del sujeto creado, su desdoblamiento y dispersión se reflejan en múltiples fragmentos de la obra, hasta el final de la misma. Allí observamos la creciente resistencia y rebelión frente al creador -Padre- y el sistema tecnocrático, capitalista y mercantil que éste representa por medio de un lenguaje logocéntrico, categorizador y opresivo:

[...] ilusiones de deseos multiplican nuestras esquizofrénicas identidades, ilusiones desatando esquizoides procesos revolucionarios, siniestras y profundas señales, paranoicos procedimientos, citados "plásticos" en el lenguaje oficial del mercadeo, producciones de deseos ejecutando acciones, como masas descompuestas atravesados por los flujos, mutamos, nos adaptamos a todo [...] cuerpos estallados, atravesados por infinidad de flujos que nos pulsan [...] la sexualidad es ahora nuestra mayor oferta, ¿desde dónde cortados contra fondos de cultura y de máquinas? [...] significaciones de este mundo de posibles, entre roles móviles [...] musa incierta, hermoso hermafrodítico feroz, respondiendo a las impuestas representaciones de paisajes familiares. ( ${ }^{a} \mathrm{Hembros}$ "Escenas para un final")

Se percibe aquí un deseo de libertad que acompaña la rebelión. Sin embargo, esta rebelión tiene dos dimensiones. Por un lado, lo que queda de la militancia es la adaptación al sistema comercial imperante, cuando el sujeto asume una sexualidad que con el tiempo se vende ("nuestra mayor oferta"). Por el otro, adopta roles móviles que, a modo de simulacros, no sólo se ajustan al mercado simbólico, sino que también ejercen resistencia a través del "hermoso hermafrodítico feroz" que responde a las representaciones impuestas con su mejor arma, la ambigüedad.

La superación de la incomunicación de estos seres sexuados, de su inhabilidad de convivir física y mentalmente, su liberación de las categorías de la masculinidad y feminidad impuestas por el sistema/creador es lo que le da a la obra un sentido de cierto optimismo al final (Kulawik, Entrevista 14). Sin embargo, el texto original de la novela-en-proceso Hembros (2008) (actualmente llamada Asedios y sin publicar) a la que se refiere Prado, y en el que se basa la instalación escénica y multimedial Hembros. Asedios a lo post humano de 2004, muestra una figura femenina híbrida y problematizada (Marta, más tarde Sofía) siempre frente a la pantalla de su computadora. En constante 
lucha consigo misma, trata de superarse construyendo una escritura: "una herencia de frases cuando no existe forma de retener sus fugas" (Prado, Correspondencia, s.p.). El texto es sumamente híbrido: tiene fragmentos en cursiva -un aparente monólogo interior o un flujo de conciencia- y hay partes en letra regular con narración en tercera persona: "Cuál Penélope, Marta ejecuta a grandes trazos una composición imprecisa" ( ${ }^{\mathrm{b} H e m b r o s ~ 15) ; ~ a l g u n a s ~ p a ́ g i n a s ~ d e l ~ t e x t o ~ e s t a ́ n ~ i m p r e s a s ~ e n ~ t i p o g r a f i ́ a s ~ d e ~ m a y o r ~}$ tamaño sobre fondo blanco o a veces negro. El texto constituye un experimento textua y conceptual: "Una bestia hermosa y cruel descansa en estas páginas aun antes que las palabras sellaran su metálica estructura" ( $\left.{ }^{\mathrm{b} H e m b r o s} 12\right)$. El giro metaficticio que vuelve el texto sobre sí mismo, con el/los sujeto/s disperso/s y fragmentado/s y narradores que fluctúan entre tercera y primera persona, constituyen un patrón de la narrativa de Prado, visible especialmente en esta novela en proceso. Lo observamos en fragmentos como el siguiente: "Enormes cantidades de otros se desplazan infinitas veces repartidos. Son mentes, cuerpos, cientos de esos otros los que circulan como tribus dispersas o desesperados insectos bajo amenaza. Una sumatoria de engendros reproduce sus pulsiones extravagantes. Ávidos de domesticación, dispuestos al roce, nos deslizamos por estas pendientes" ('Hembros 13). La identidad cyborguiana de la protagonista se conforma en un largo proceso de autoindagación-escritura frente al computador: "Sobrepasada por su incapacidad de descifrar todas las variables que se le escapan, que no maneja, Marta puede verse con el rostro pegado a la pantalla del computador, y ver a esa mujer con el cuerpo mediatizado por la máquina" ( ${ }^{b}$ Hembros 18-19). Su identidad se dispersa, se transforma y se diluye; ya no es una, sino otra, una multiplicidad de seres mediatizados por el sistema, por la máquina que la absorbe. Los ejemplos textuales abundan: "La realidad extendida late y se multiplica" ("Hembros 13); "Su rostro bien podría ser de otra, en cualquier otro lugar" ('Hembros 19). "Una máquina incierta y peligrosa nos separa de mundo. Una vez adentro, jamás abandonas el sistema" ('Hembros 20). "Marta miente, lo hace todo el tiempo, justificando su performática representación se despliega y se imagina en esa enorme cantidad de otros que transitan como en un diminuto enjambre" ( ${ }^{b}$ Hembros 22). En medio de esta dispersión del sujeto, se pierde el argumento de la novela, la "historia" (de una Marta humana) y en ese despliegue se deconstruye como una "histeria formidable" ('Hembros 22)

EL COFRE

De manera semejante, en la novela poética $E l$ cofre tampoco hay un argumento aparente. El discurso es un fluir de consciencia del personaje principal femenino que evoca una relación rota con un hombre de quien intenta liberarse a través de una relación diferente, posiblemente lésbica. Gradualmente, vuelve a acercarse al hombre rechazado en un proceso de transformación interior. La narración en tercera persona se funde indiscriminadamente con la de primera persona, además de usar la segunda persona de una manera apelativa y un foco variable: "Fuiste dividida, propagada, mutilada creyéndote atemporal en aquella unidad con tus quejidos me ofrecías despojada" ( $E l$ cofre 18). "Libertida, recorrerse como pieza más una de las tantas, creatura tramada del deseo de voces ocultas en un cofre" (20). La relación heterosexual inicial se desplaza hacia una relación homosexual-lésbica cuando el sujeto hablante-el narrador (femenino por las marcas gramaticales)- se refiere a un objeto de deseo también femenino: "Nos importábamos más la una en la otra" (48). Este sujeto femenino doble (o desdoblado) llega a los extremos de la exuberancia y artificio en su rebelión antimasculina: se maquilla excesivamente, se transforma en un espectáculo ambulante, sale a las calles sombrías de la ciudad ocupada por el represivo régimen militar desdoblándose y perdiéndose, en anonimato buscando al otro: "Insaciada se busca repetida se hace rito en silencio se desborda" (29); "[...] contorneada por los brillos del consumo, [...] Quiere poner en acción esa imagen [...]" (30); "[...] allí se desarrollaba el espectáculo" (33). "Luego de sus dulces sueños se reduce a desatado despojo de su múltiple fachada" (36). Estas últimas palabras sugieren el estado de dispersión del sujeto. La relación homosexual avanza hacia la disolución de los rasgos sexuales (externos e internos) fijos, los individuos-personajes (ella, él, ello) se vuelven indistinguibles en términos de hombre mujer. Abundan ejemplos de esta indefinición a lo largo del texto: "Todos seríamos indefinidos, ya no habrían diferencias" (49). "Buscándose la una en la displicencia de la otra" (50). "[A]mbas enrojecieron, luego apareció la dulce sonrisa de la comunión [...] descubren la carencia de falo" (59). "Era un solo pedazo de carne descubierto. Era un soplo de aliento sin formas" (67). "Maldita es en su propia indefinición maldita en la infinidad de sus pliegues" (71). "Se imagina penetrándolo, hasta deshacerle esa piel de cemento que impide la plenitud del compacto. [...] (cuerpos que flotan se vuelven formando un círculo hacia adentro)" (72): "[...] la renacida de otra raza se desborda" (73). La inestabilidad de referentes masculinos / femeninos es notoria, hasta llegar al punto de sugerir una relación más nítidamente homosexual: "La descubre otra, $[\ldots]$ Luce distinta, [...] Tiene marcas en la cara y su cabeza... no entiendo, luego de habe cuidado tanto ese cabello 'Ella me asusta'-" (74). "Como una poseída luce intensa su mirada" (75)

Como acabamos de observar, un elemento constante en las obras de Prado es el estado inestable del sujeto y su simultáneo desborde de rasgos móviles de apariencia y de orientación sexual. Este lábil estado femenino, de ser "el-la", sin forma ni límites ni categorizaciones se conforma en el lenguaje mismo, por medio de las palabras que la in-definen: "ELLA por su parte / es a la vez una resuscitada una pesadilla dispuesta en escritura / Es lo femenino / en las cicatrices de su cuerpo / en la profundidad de sus heridas / en la agonía de sus desbordes [...]. / Es una máscara colmando apetitos [...] ELLA es todo un espectáculo / en la trayectoria de su recorrido" (80, mayúsculas en 
original, / marcan versos separados en texto original); "En ese lugar nuestro, sitio de una espera sin tiempo. Donde se unieron los cuerpos vaciados los que se arrastraron, los que desaparecieron" (83). El sujeto se oculta detrás de un cuerpo, una máscara, recurre a la simulación, y su actuación / performance corporal solamente contribuye a que se perciba su identidad como móvil y transitiva. Este sujeto femenino llega progresivamente a un estado de disolución en su búsqueda de la comunión (o fusión) con el "otro". El clímax del argumento (tan difícilmente perceptible en esta novela) lo constituye el lograr una unión perfecta (aunque en tránsito perpetuo) y una fusión con el otro: "Pero estaba allí, ese sitio nuestro donde ya no entendemos diferencias, lugar único de saltos donde las dimensiones se precipitan y se abren las grietas, [...] un solo cuerpo hecho carne en el vientre de otra arquitectura. [...] Acceder en el no tiempo era modo único de un hacer de esta fusión de los apátridas, nacidos por azar en la época del boom" (85-86). La fusión de seres se produce luego de una búsqueda y transición largas, un movimiento transgresivo sin saber si del todo concluido.

\section{LÓBULO}

La tercera novela de Prado, Lóbulo (1998), presenta la historia de Sofía, un alma perdida de aproximadamente veinte años. Confinada al espacio de su habitación dentro de una vieja casona, en lo que un lector podría suponer como Santiago, capital chilena, Sofía lucha con sus demonios: las imágenes de un padre al que nunca conoció (éste dejó la casa cuando ella era una recién nacida), una invasiva madre que manipula y corrige a la hija en todo lo que hace y, sobre todo, el teléfono que timbra cada noche para revelar la voz de un hombre desconocido que la hipnotiza. Este gradualmente invade todo su espacio existencial, violando incluso (tal vez metafóricamente) su cuerpo joven. La desintegración progresiva de la subjetividad de Sofía la lleva primero a un estado de locura, luego a un embarazo y finalmente a su muerte. Mientras está muriendo, Sofía da a luz pliegues de papel impreso: su texto es "el libro" de su existencia, de sus experiencias interiores de desintegración, de la disolución de su identidad. La fusión entre su cuerpo, su mente y el teléfono produce lo que varios teóricos como Deleuze y Guattari, además de Hayles y Haraway, han explicado como un cyborg, o un ser androide con rasgos ambiguos entre humano y máquina, entre masculino y femenino.

Desde una dimensión metafórica, la novela ilustra el fenómeno de la disolución del espacio comunicativo inter-humano en medio de la invasión de la tele-tecnología que, irónicamente, está diseñada para mejorar la comunicación entre los humanos. En un giro metaficticio, la voz del/la narrador(a) interviene abruptamente, como podemos observar en el texto: "[...] ¿o no piensa que en este mundo contemporáneo el teléfono configura un escenario absurdo? Mire bien, fíjese en toda esa gente por las calles, con la mirada trasladada a la boca de sus teléfonos celulares [...]" (Lóbulo 71). Con plena conciencia metaficticia e incorporando directamente al lector (narratario), la voz narrativa constata, con un claro tono crítico, que "[e]l teléfono es un mero instrumento para hacerle participar de un proceso de comunicatransacción que he imaginado [...] en un escenario delimitado por alucinaciones, un personaje inconexo, anacrónico, hasta con algunos efectos de descalce? Somos intentos intervenidos por llamadas retocadas usted y yo en un acto extremo de incomunicatransacción" (70, énfasis en original) La identidad del individuo se disuelve entre una multitud de almas perdidas, como lo es ella misma, que desesperadamente buscan contacto con "otro" por medio de la tecnología. El/la narrador(a), otra vez con la apelación al narratario, lo comenta de un modo crítico, hasta analítico:

[Sofía] No [es] más que otro personaje que ocupa un espacio entre tantas otras Sofías que deambulan por allí, quizás, en viejas casonas. Pero si se fija bien, existe en Sofía una proximidad, como si ella tuviese conciencia de que existe algo más. Incluso sería capaz de inventar otros personajes, sabiendo que ninguno podrá acompañarla. Busca en ese teléfono, porque en el aparato de plástico rojo está todo lo que necesita para mirarse en la ausencia de otro. Todos estamos ausentes. (114)

El sujeto-protagonista-Sofía sufre una transformación, una mutación en que se desestabiliza su integridad, se descompone su identidad estable de mujer y de joven. Su comportamiento cede a la voluntad del hombre acosador que usa únicamente su voz (el lenguaje) como instrumento de dominación. La distinción entre los dos sujetoscuerpos-voces progresivamente se deshace: "Las sensaciones caen nítidas, mi cuerpo sumergido cambia de forma, empieza a moverse casi independiente, ondulante en el agua se separa de mi mente. [...] soy otra naciendo desde el agua" (118). Los dos seres y sus voces se vuelven ambiguos en este confuso (por el uso de diferentes pronombres personales) diálogo virtual (a distancia), se con-funden al traspasar los límites de uno y otro, de hembra y varón, de humano y aparato, resultando en un ser cyborg:

El hombre se defiende, y para defenderse las palabras, como último recurso:-Temes desaparecer en tu cabeza, -dice-tu propia metamorfosis no es suficiente... los gemidos se atenúan, luego hay silencio. -Arrastrándote escapas, ofidio peligroso [...] el hombre gime - en principio fuimos ambos uno solo. Aumentamos la idea que hizo otra carne, como de la costilla se hace en la historia a la hembra, [...] La lengua lo traspasa todo, serpenteante secreta saliva en abundancia, la piel resbala entre las escamas córneas. (132, cursiva en original)

Además, se borra la distinción entre humano y animal sin que se pierda la unión sensual, eróticamente cargada: "A pesar de las palabras dolorosas, y a pesar de ella misma, lo acaricia. [...] Poco a poco ambos cuerpos van haciéndose cada vez menos nítidos..." (133). Aquí, en seguida la narración sugiere la idea de que ocurrió un acto sexual.

Revista Iberoamericana, Vol. LXXIX, Núms. 244-245, Julio-Diciembre 2013, 743-758 \begin{tabular}{ll}
\hline ISSN 0034-9631 (Impreso) & ISSN 2154-4794 (Electrónico)
\end{tabular} 
Solamente por medio del lenguaje Sofía sobrevive esta disolución de su identidad humana y su transformación en un cyborg: hablando consigo misma y escribiendo por su cuenta; así no se silencia, no desaparece, aún no perece: "Lleva muchos días encerrada sin entender lo que le ocurre exactamente, tampoco lo desea. No quiere hablar con nadie. Se encierra a escribir cosas que luego destruye. El dormitorio está completamente revuelto y el suelo va llenándose de papeles arrugados"(135). En su constante búsqueda del otro en el espacio virtual del teléfono, se transforma en otro, muta su identidad, asume diferentes aspectos, e incluso cambia de identidad étnica: "Tengo que salir de toda convención para aplacarlos [hombres]. Me hago india. India bailo, como si fuera uno de ellos, india como todos, me hago parte, india mi carne persiste" (136). Se somete a un proceso de transformación completa, hasta de metamorfosis en la que la máquina (el auricular del teléfono) y el sexo masculino se confunden (o complementan): "Su cabeza no es la misma -me responde él-, sus brazos desaparecen casi por completo cuando me atrevo a seguir la elongada forma de su sexo" (142). “-Porque antes de que recorriera con imprecisión sus manos en el teclado tratando de imaginarme, ocurrirá su metamorfosis-dice-ya no puedo seducirle unida"(144). Pasando por etapas de reflexión y perdiendo su integridad física, Sofía se transforma por completo, pierde su identidad de mujer adolescente chilena: "Conoce el trance al punto de verse transformada" (66) Llega a un estado de tal mutación que su cuerpo adquiere la consistencia de una cáscara hermética de metal o plástico, como un cyborg -un híbrido entre humano y máquina una extensión de la máquina, según tanto Hayles $(3,283)$ como Haraway (Simians 149 , 176)- inflexible al exterior: "Mi cuerpo cambia transformándose poco a poco en una coraza resistente. [...] Desde aquel cuerpo informe, otro y desbordado, digo: apenas un susurro" (Lóbulo 148). El final de la cita anterior y la siguiente reflejan el simultáneo estado de fluidez y fragmentariedad del sujeto, que ya no posee una id-entidad sino una alter-idad: "Ir haciéndose a pedazos entre los fragmentos, deshaciéndose en imágenes desmembradas, apartarse de la ficción. Sólo fragmentos, destellos luego sombras" (45).

A pesar del hermetismo que sugiere la coraza, estamos frente a una apertura de cuerpo y de la integridad / identidad de Sofía. En su estudio de la novela Lóbulo, J. Andrew Brown nos ofrece una apreciación de este fenómeno al referirse a una "apertura carnal": "Presenciamos, entonces, la articulación de una identidad corpora no hermética, donde la carne no establece límites identitarios que mantendrían a una Sofía cerrada. Este momento de apertura carnal establece el contexto para los eventos que penetrarán en el imaginario de Sofía [...]” (804). Por su lado, Prado confirma que la mutación y la acompañante adaptabilidad son elementos claves en esta novela: "somos bichos tecnológicos, y nuestra humanidad está cruzada con la tecnología. Sin computador no somos nada; yo vivo en mi computador" (Kulawik, Entrevista 8). Estas ideas de la penetrabilidad apuntan más contundentemente hacia el motivo de la fusión de cuerpos vivos con máquinas, señalado antes por Haraway: "el cyborg es un ser híbrido de carne y aparato tecnológico que, por esa hibridez, desafía las clasificaciones de la sociedad tradicional" (Brown 802). Hacia el final de la novela, este proceso resulta en la formación de un cyborg auténtico, es decir, en un ser poshumano. Su identidad fragmentada termina en la disolución total del "yo", ahora fundido con el "otro": "Sofía se abandona, desdoblada la otra, combate entre ideas de estabilidad y agitación. Es allí donde teme enfrentársele, aquella bestia no tiene nombre de mujer" (Lóbulo 153) Aunque está presente el otro, la comunicación resulta truncada e inefectiva: "Estamos tú y yo distantes, ajenos a cualquier placer entre nuestras carnes. Ajenos" (155). La desintegración de su identidad humana ocurre entre intentos de fusión con otro: "Sofía va desapareciendo, en el equilibrio ambos traspasan su soledad, ambos van haciéndose al vacío. [...] Nadie podrá evitar que ambos se fundan a través de los traspasos" (172). El estado resultante es el cyborg, o fusión entre humano y máquina-Sofía y el teléfono-y su modus operandi es un sistema artificial de sonidos y signos: el lenguaje. La fusión se consuma con la fecundación de la protagonista por la voz en el teléfono: “¿No es acaso una ironía que él no tenga cuerpo? ¿no lo crees así? Fuiste fecundada en este laberinto de sonidos -dice él" (204). La voz del extraño al otro lado de la línea y la del/ la narrador(a) mismo/a (se) con-funde(n).

La transformación de la identidad humana en una "alteridad" o "afinidad"poshumana, en este sentido semejante al cyborg (Haraway, Simians 155), está acompañada por una relación cercana (afín) entre forma y contenido. La disyunción entre ser/voz humana y un cyborg (disperso) poshumano se refleja en las novelas de Prado en el tejido mismo del texto narrativo, en el lenguaje exuberante, erotizado y artificioso (como el de las máquinas) que producen las ondas electromagnéticas del teléfono. También se refleja en la narración cambiante y dispersa, cargada de elementos metaficticios, llena de giros discursivos que socavan cualquier uniformidad de género literario. En su análisis de la identidad poshumana en Lóbulo, J. Andrew Brown ofrece una interpretación valiosa de este juego entre forma y contenido dentro de la novela: "Vista de esta forma, no sería una interpretación riesgosa sostener que Lóbulo combina una hibridez genérica con una presentación singular de identidad femenina en una realidad cada vez más constituida de tecnología y prótesis artificial" (803). Es interesante observar esta relación distintiva entre una subjetividad desligada de la realidad y una narración fragmentada que la mimetiza a modo de impulsos electromagnéticos producidos por el teléfono en el cuerpo de Sofía. En correlación cercana con estos impulsos, los que alteran su identidad, están los cambios en la voz narrativa: de tercera a primera persona, y viceversa, y a veces a segunda persona. El contacto entre humano y máquina resulta en su unión, visible en la (con-)fusión de las voces narrativas con las de los personajes. Brown señala esta relación entre la subjetividad descompuesta y el texto fragmentado de la novela: "Prado acentúa los cambios eléctricos (y metafóricos) del cuerpo de Sofía con una división de identidad en donde la narradora vacila entre tercera y primera persona, junto al 
poder eléctrico que causa también cambios abruptos en la narración misma" (808) El crítico observa y comenta la aparición del cyborg que progresivamente invade y se funde con la protagonista: “[...] el acto erótico aquí ocurre no tanto entre las voces de los amantes sino entre los dedos de Sofía y los orificios del teléfono, el contacto de carne y máquina resultando en una unión completa en que carne y máquina se mezclan sin poder distinguirse el uno del otro" (809). Este razonamiento sigue en la línea de pensamiento de Hayles: "[...] the posthuman view configures human being so that it can be seamlessly articulated with intelligent machines. In the posthuman, there are no essential differences or absolute demarcations between bodily existence and computer simulation, cybernetic mechanism and biological organism, robot teleology and human goals" (3).

Después de meses de conversaciones telefónicas, el cuerpo "cibernético" de Sofía se convierte en una "impresora orgánica" de textos en papel que salen de su cuerpo y causan su muerte, por lo menos en el sentido físico. El nacimiento de un hijo-texto puede interpretarse tanto como una rebelión antipatriarcal como la continuidad de su ser por medio del lenguaje, su inmortalidad. Más allá de ser revolucionaria, Sofía, con toda su pasividad, es transgresiva de la norma patriarcal por su ambigüedad. Habiéndose transformado en cyborg, llega a ser víctima de una presencia masculina virtual y mecánica. No obstante, como observa Brown, en vez de oponerse a la fuerza masculina, su "cuerpo cibernético figurativo lleva la prótesis tecnológica como emblemas de su violación" 810). Su resistencia se muestra en su producción textual que le posibilita la enunciación de experiencias a través del lenguaje. Esta idea constituye un aporte original de Prado a la teoría de la identidad poshumana formulada por Hayles y Haraway: "El cuerpo mecánico de Sofía, que se subraya con su conversión en impresora, la conecta con la idea del cuerpo subversivo cuya habilidad de escribir rehúsa ser callada" (Brown 811).

De manera algo antitética a lo expuesto por Brown, Martín Hopenhayn indica la posibilidad de una esclavización total del sujeto - de la protagonista: "una mujer poblada de voces y teléfonos posibles" ("No Way Out" 1)- esclavización que ocurre por medio del lenguaje -una herramienta de dominación patriarcal-. La del teléfono es una voz masculina que puede representar simultáneamente al hombre desconocido, al niño engendrado o al padre ausente de la protagonista. El acto final de escritura que realiza Sofía parece un intento desesperado de liberarse, como vemos en el episodio en sus intentos por arrancar la serpiente que domina el cuerpo de Sofía, de "ese hombre imaginario que la habita" ("No Way Out" 1). Con todo, Hopenhayn observa que, siendo el traspaso (en sus múltiples dimensiones) el leitmotiv guiador de la novela, es el parto aborto del hijo-serpiente (presencia masculina dominadora) que representa un intento fallido de liberación. También este crítico llama la atención hacia el motivo del traspaso reflejado en el empleo transgresivo de las técnicas narrativas:

Z7. Revista Iberoamericana, Vol. LXXIX, Núms. 244-245, Julio-Diciembre 2013, 743-758 ISSN 0034-9631 (Impreso) ISSN 2154-4794 (Electrónico)
Hay que lograr el traspaso, extirpar la serpiente. Pero con ella, la escritura que también se traspasa desde la tercera a la primera persona , desde Eugenia a Sofía, y que exorciza a la vez que siembra demonios. [...] Está maldita. Su intento por salvarse es siempre el gatillo que la liquida. Está de atar, [...] hecha [sic] de frases inconclusas, insuflada por voces, intoxicada por pedazos de papeles llenos de letras que han terminado por llenarla y vaciarla a la vez. ("No Way Out" 3)

Según esta aproximación, Sofía es un personaje frustrado, una víctima del poder masculino y sus esfuerzos, aunque revolucionarios, en última medida fracasan.

\section{ENVOLTURAS NEOBARROCAS}

El trabajo que hace Prado con el lenguaje es tal vez el rasgo más prominente de su escritura, especialmente en las obras que acabamos de analizar. La acerca a lo que se conoce en los estudios literarios y del arte como el barroco moderno, o el "neobarroco". En la entrevista, la autora afirma que "[...] es un trabajo de lenguaje; voy apretando y sacando y poniendo y moviendo las palabras. Trabajo mucho en la sintaxis, alterándola [...] y ahí siento que los textos brillan como perlas, mis pequeñas joyas" (Kulawik, Entrevista 12). Las palabras, la sintaxis y la lengua se transforman de portadores de mensajes e ideas en una especie de cemíes (o amuletos) que evocan estados y sensaciones, identidades (o "alteridades") nuevas. El motivo de la serpiente al final de Lóbulo revela otro elemento que acerca su escritura al barroco: la metamorfosis, observable en el paso de la voz masculina a una culebra que se radica en el cuerpo (vientre) de la protagonista. Del mismo modo, esta serpiente-lenguaje que la domina, se transforma en feto en el vientre de Sofía, para luego convertirse en su propio hijo-texto que ella misma crea y da a luz al final de la novela; irónicamente es la misma novela que leemos. Este procedimiento metaficticio se cierra sobre el texto, como la serpiente que muerde su cola. Es un giro que lo acerca a otros textos neobarrocos en América Latina que contienen elementos de metaficción; por ejemplo, a los del cubano Severo Sarduy (con motivos semejantes visibles en Colibri y Pájaros de la playa), del argentino Osvaldo Lamborghini (Sebregondi retrocede y El fiord), de las brasileñas Clarice Lispector e Hilda Hilst, y de la chilena Diamela Eltit (paralelismos visibles especialmente con la novela El cuarto mundo). Las obras de estos escritores han sido descritas como neovanguardistas no solamente por la experimentación con la forma narrativa, sino por su atención pormenorizada hacia el lenguaje (Kulawik, Travestismo 40-41, 303-304).

En el prólogo titulado "La extraña tonalidad del lenguaje tránsfuga de Eugenia Prado", que aparece en la segunda edición de El cofre (2000), el escritor y teórico chileno Juan Pablo Sutherland describe con sutileza casi poética las características definidoras de la narrativa de Prado. Resalta algunos rasgos importantes que acercan su escritura a lo que venimos llamando el neobarroco: "una voz y una estrategia [...] que no

Revista Iberoamericana, Vol. LXXIX, Núms. 244-245, Julio-Diciembre 2013, 743-758 ISSN 2154-4794 (Electrónico) 
refieren un lugar sino a una multiplicidad de sentidos, gestualidades y alumbramientos" (8), "lengua que desafía al logocentrismo escritural del hombre", "fuga al discurso militante", "una señal de autismo genérico disolviendo las oposiciones binarias de lo masculino y femenino" que "politiza el cuerpo en tanto disidencia" (9). Sutherland señala "la disolución de los géneros" (otro rasgo asociable con el neobarroco) como uno de los puntos claves que atentan "contra el orden simbólico [para] invadir las cárceles significantes del andamiaje masculino y femenino, [para] parodiar la escena corpora de la voz masculina en tanto asedio" (10), desalojando el orden simbólico de la ley de padre. Entre otras características, menciona la fragmentariedad versus la totalidad "de un lenguaje narrativo que apela a una inquietud, a una extra-polación [...] preguntando al lector militante sobre las trampas de las convenciones tanto sexuales como genéricas" (13). Según este comentador perspicaz del estilo y lenguaje de Prado, las estrategias de la escritora chilena "se desplazan por una interrogación al canon, a la disolución de lo masculino y femenino" (15). La escritura tránsfuga de Prado "ha generado una sugerente zona imaginaria que desafía al orden simbólico, al logos masculino [... interrogando a la centralidad del poder" (16). Las características que señala Sutherlan nos indican un uso altamente elaborado y consciente de la lengua (y del estilo), siendo este uso una herramienta poderosa que Prado emplea a partir del lenguaje y aplica a su escritura a manera neobarroca, ubicándose así en el contexto más amplio de la literatura neovanguardista latinoamericana. Su estilo encuentra una aplicación conveniente en la expresión de oposiciones irreconciliables como varón / hembra y en la creación de identidades nuevas poshumanas, como los cyborgs, a partir de los escombros de las categorías tradicionales. En términos de Ricardo Loebell, teórico y académico chileno, Prado recurre a un lenguaje y una mirada hermafrodita, es decir polidimensional, de mundo; emplea un lenguaje con el que se desliza hacia una dimensión metanarrativa para generar un texto que no se subordina a ningún género literario en particular, sino que procura el conocimiento más abarcador de la "situación humana" a partir del lenguaje (Loebell 2, 6). Como afirma la autora en la entrevista concedida a Loebell, "existe un sentido en mi escritura, un sentido obsesivo que busca descifrar hacia la intimidad, hacia la profundidad del ser", en una búsqueda constante de conocimiento (3).

Nuestro análisis permite observar la creación de una (des-)identidad poshumana en las obras de Eugenia Prado. La presencia de sujetos poshumanos señala un posible estado de crisis que se perfila en el Occidente a finales del siglo xx y comienzos del XxI, que lleva a la desintegración de las identidades estables, de los personajes ficticios y a la sublevación de la lengua española. La deconstrucción de género -sexual y literario, en "un desplazamiento permanente" (Loebell 8)- es solamente uno de los numerosos reflejos de una fisura que lacera la cultura postmoderna. Es un cambio de valores y creencias, una duda de las categorías e identidades estables producida por las cada vez más hondas recesiones económicas y revueltas políticas de los siglos Xx y XxI. Estas crisis, provocadas por las élites neocoloniales y patriarcales en poder, han exacerbado las tensiones sociales y, asimismo, han provocado reacciones más radicales tanto en las artes, por la experimentación más extrema, como en la literatura, por la deconstrucción del lenguaje y de las estructuras narrativas.

En el contexto propiamente chileno, la reacción a esta crisis "neoliberal" ha sido especialmente visible desde la década de los ochenta en la narrativa neovanguardista (con ciertos rasgos neobarrocos) en la vena de las obras de Diamela Eltit, Juan Pablo Sutherland, Pedro Lemebel, Francisco Casas, además de las de Eugenia Prado. El tratamiento altamente elaborado del lenguaje y de las formas narrativas y la combinación indiscriminada de varios géneros literarios en el espacio de una sola obra (rasgos que caracterizan las obras narrativas de estos escritores) indican una respuesta artística y estética radical a la crisis social del Chile neoliberal de las últimas tres décadas.

Podemos hacer una pregunta final: ¿es posible una recuperación cultural con la ayuda de la nueva creación artística y literaria, por medio de nuevos modos de expresión y, sobre todo, con la aparición de nuevas identidades andróginas y posthumanas? En la novela de Prado leemos: "Traer el pasado / renovar lo disperso / desde cada pliegue descifrarlo" (El cofre 92). Este puede ser un modo de salvarse del miasma del arte comercial de la era neoliberal. Tal vez sea necesaria una constante reinterpretación y reformulación de la identidad, una apertura indiscriminada, un cambio y transformación del "yo", así como lo presenciamos en la letra del Canto 9 de Hembros, "Azumbro": "[...] todos los días la imagen, incluso tu propia imagen, puede ser modificada". Prado admite que hay un deseo obsesivo en su escritura por descifrar la intimidad, por buscar el conocimiento y estados más profundos de la existencia (Loebell 2-6). Demuestra un afán por acceder a una realidad otra que yace dentro y más allá del "yo" socialmente determinado, una realidad humana transgenérica y andrógina que se revela desde el punto de vista de un/a hermafrodita - un nuevo sujeto andrógino, un nuevo "yo"-

\section{BibLIOGRAFí}

Brown, J. Andrew. "Identidad poshumana en Lóbulo de Eugenia Prado". Revista Iberoamericana LXXIII/221 (2007): 801-812.

Deleuze, Gilles y Félix Guattari. Anti-Oedipus: Capitalism and Schizophrenia. Minneapolis: U of Minnesota P, 1983.

Haraway, Donna J. Simians, Cyborgs, and Women: The Reinvention of Nature. New York: Routledge, 1991

Modest_Witness@Second_Millenium.Female Man_Meets_Oncomouse. Feminism and Technoscience. NewYork: Routledge, 1997.

Hayles, N. Katherine. How we Became Posthuman: Virtual Bodies in Cybernetics, Literature, and Informatics. Chicago: U of Chicago P, 1999.
Revista Iberoamericana, Vol. LXXIX, Núms. 244-245, Julio-Diciembre 2013, 743-758 ISSN 0034-9631 (Impreso)
Revista Iberoamericana, Vol. LXXIX, Núms. 244-245, Julio-Diciembre 2013, 743-758 ISSN 0034-9631 (Impreso) ISSN 2154-4794 (Electrónico) 
Hopenhayn, Martín. "No Way Out: Comentario a Lóbulo de Eugenia Prado". Crítica. cl.Revista Digital. 24 febrero 2005. <www.critica.cl>. 25 septiembre 2010.

Kulawik, Krzysztof. Entrevista con Eugenia Prado. Grabación digital, 22 de marzo, 2009. Transcripción sin publicar. 1-34.

Travestismolingüístico: el enmascaramiento de la identidad sexual en la narrativa latinoamericana neobarroca. Frankfurt: Iberoamericana-Vervuert, 2009.

Loebell, Ricardo. "Repeso de un ensayo: a propósito de la narrativa de Eugenia Prado". Literatura y lingüística. Santiago de Chile. 12 (2000). <http://www.scielo.cl/scielo. php>. 25 septiembre 2010.

Poblete, Nicolás. "Engendrando el texto posthumano en Lóbulo de Eugenia Prado". Crítica.cl.Revista Digital.20julio 2000. $<$ http://www.critica.cl $>.30$ septiembre 2010.

Prado Bassi, Eugenia. El cofre. Santiago de Chile: Caja Negra, 1987. ${ }^{a}$ Hembros: asedios a lo post humano. Novela instalación. Folleto con texto-guión del CD con video y música. Beca Fondart Artes Integradas / Chile, 2004.

${ }^{\mathrm{b}}$ Hembros. Novela (en proceso). Santiago de Chile: autoedición, $1^{\mathrm{a}}$ impresión 2008. Retitulada como Asedios en 2011. Lóbulo. Santiago de Chile: Cuarto Propio, 1998. $<$ http://eugeniaprado.blogspot.com/>.

Correspondencia con Krzysztof Kulawik ("Currículo" de la escritora, otros documentos y mensajes). Sin publicar, 2010-2011. 1-18.

Sarduy, Severo. Escrito sobre un cuerpo. 1969. Reeditado como Ensayos generales sobre el Barroco. Severo Sarduy. México: Fondo de Cultura Económica, 1987. 225-317. La simulación. 1982. Reeditado como Ensayos generales sobre el Barroco. Severo Sarduy. México: Fondo de Cultura Económica, 1987. 51-142.

Sifuentes-Jáuregui, Ben. Transvestism, Masculinity, and Latin American Literature. Genders Share Flesh. New York: Palgrave, 2002.

Streeter, John, Eugenia Prado y Cristóbal Rojas. Hembros la música. Novela instalación. CD con video y música. Beca Fondo de la Música - Chile, 2005.

Sutherland, Juan Pablo. "El cofre, la extraña tonalidad del lenguaje tránsfugo de Eugenia Prado”. Prólogo a El cofre. De Eugenia Prado. $2^{a}$ edición. Santiago de Chile: Surada Gestión Editorial, 2000. 7-16. 